\title{
Bysykler redder liv
}

\section{Utplassering av sykler gir store helsefordeler og lite helserisiko. Dette viser en ny studie fra Barcelona.}

Utplasserte sykler blir et stadig mer populært fremkomstmiddel i storbyer i alle verdensdeler. Den fysiske aktiviteten ved sykling anses som gunstig, men eksponeringen for luftforurensning og trafikk kan utgjøre en helserisiko. Nå har en internasjonal fors-

Illustrasjonsfoto Colourbox kergruppe undersøkt helseeffekter ved bruk av bysykler i Barcelona (1).

Studien omfattet over 180000 sykkelabonnenter. Estimert årlig endring i mortalitet for disse var 0,03 dødsfall fra trafikkulykker og 0,13 fra luftforurensning, sammenlik-

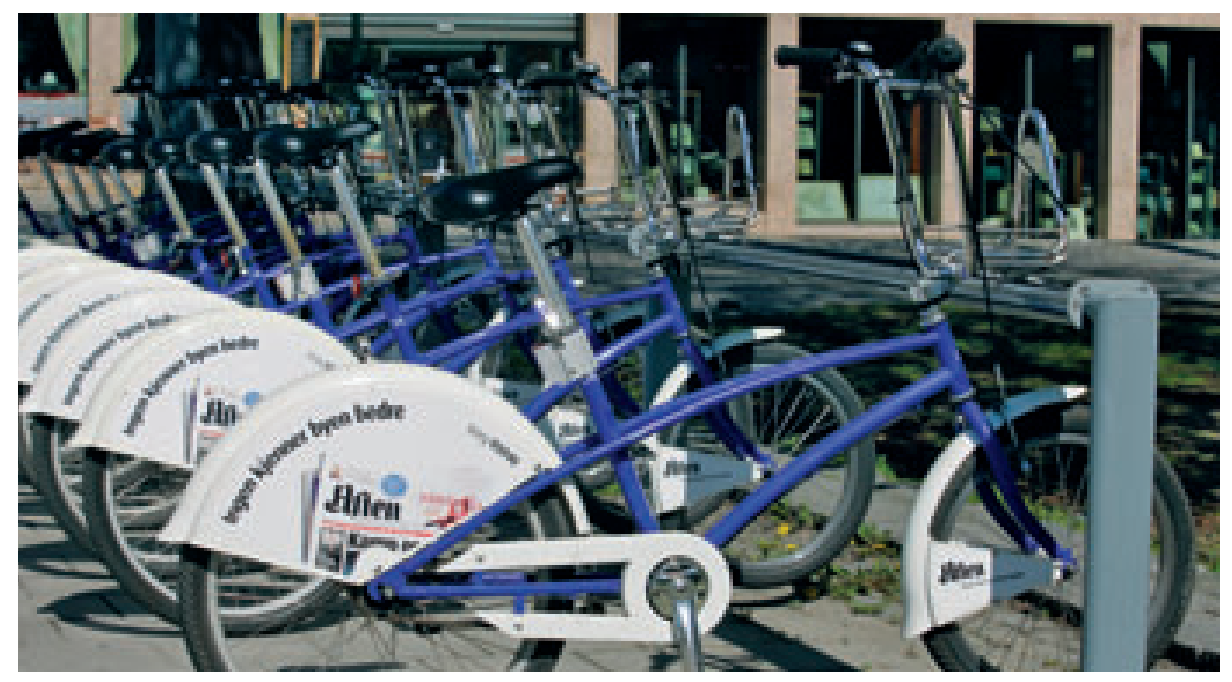

net med brukere av bil. 12,46 dødsfall ble unngått som følge av fysisk aktivitet. Årlig sparte liv var dermed 12,28. Sykkeldelingen førte til en estimert reduksjon i $\mathrm{CO}_{2}$-utslipp på over 9 millioner kg.

- Denne studien viser spennende resultater og indikerer at det er et stort helsepotensial ved å få flere til å sykle, sier professor Elling Bere ved Institutt for folkehelse, idrett og ernæring ved Universitetet i Agder.

- Nyere forskning viser at sykling, som vanligvis gir høyere fysisk intensitet enn det å gå, kan ha særlig stor effekt på helsen. Studier fra Norge og Nederland viser f.eks. at ungdomsskoleelever som sykler til skolen, i mindre grad er overvektige enn dem som ikke sykler.

- Utplassering av sykler skal få folk til å sykle mer. Det er også viktig å få flere til å sykle mer med egne sykler. Vi trenger mer forskning på hvilke faktorer som er viktige for å få folk til å sykle, sier Bere.

\section{Trine B. Haugen}

trine.b.haugen@hf.hio.no

Tidsskriftet

Litteratur

1. Rojas-Rueda D, de Nazelle A, Tainio M et al. The health risks and benefits of cycling in urban environments compared with car use: health impact assessment study. BMJ 2011; 343: d4521.

\section{Screening for personlighetsforstyrrelse?}

\section{Fullt diagnostisk intervju for per- sonlighetsforstyrrelse er tid-og ressurskrevende. Et screening- instrument kan identifisere pasienter der et slikt intervju vil gi positivt resultat.}

Omtrent halvparten av pasienter henvist til poliklinisk psykisk helsevern har personlighetsforstyrrelse. Gullstandard for diagnostisk utredning av slike tilstander er et semistrukturert klinisk SCID II-intervju, som tar 1-2 timer. Korrekt diagnostikk er viktig med tanke på sykdomsforløp og valg av behandling.

Iowa Personality Disorder Screen (IPDS) er et screeningsinstrument med $11 \mathrm{ja} /$ neispørsmål. Ved Hamar distriktspsykiatriske senter har vi sammenliknet pasientenes IPDS- skår med funnene på deres SCID II-intervju (1). Pasientene ble rekruttert av erfarne terapeuter som var trent i bruk av SCID II, og som var blindet for IPDS-skåren. I alt 145 intervjuer ble gjennomført. Vi ekskluderte pasienter med psykose, rusavhengighet, $\mathrm{AD} / \mathrm{HD}$, alvorlig depresjon med suicidfare, språkvansker og psykisk utviklingshemning.

Basert på SCID-II som gullstandard hadde 73 pasienter akse I-lidelser med komorbid personlighetsforstyrrelse og 72 kun akse Ilidelser. Ved en grenseverdi på IPDS på $\geq 4$ ja-svar var sensitiviteten 0,77 og spesifisiteten 0,71 for personlighetsforstyrrelse. En kortversjon på fem spørsmål hadde like gode egenskaper ved grenseverdi på $\geq 2$ ja-svar. Psykososiale variabler, komorbid angst og depresjon samt globale symptom- og funksjonsmål påvirket ikke screeningegenskapene til IPDS.

Dersom SCID II-intervju inngår i en spe- sialistutredning ved distriktspsykiatriske sentre, betyr våre funn at for 100 henviste pasienter kan IPDS-screening spare 47 overflødige intervjuer. Samtidig er det en risiko for å overse 11-12 pasienter der personlighetsforstyrrelse ikke fanges opp av IPDS. Vi mener at IPDS-screening kan være et nyttig supplement til klinisk skjønn.

\footnotetext{
Ingrid Olssøn

ingrid.olsson@sykehuset-innlandet.no

Hamar DPS

Sykehuset Innlandet

Litteratur

1. Olssøn I, Sørebø Ø. Dahl AA. A cross-sectional testing of the IOWA Personality Disorder Screen in a psychiatric outpatient setting. BMC Psychiatry 2011; 11: 105.
} 